\title{
The Notion of Sunna: An Eclectic Reading in the Ibadhi Legacy
}

\author{
AHMED AL-KINDI* \& ANKE IMAN BOUZENITA ${ }^{1}$
}

\begin{abstract}
This paper offers a cursory reading in the Ibadhi legacy, drawing on its diversity in place and time. It investigates the notion of sunna in its different meanings and connotations in this legacy, in the linguistic, usuli and fiqhi usage as well as at its intersections with hadith, athar and sira. The article documents the rich and independent legacy of the Ibadhi school. It concludes that, apart from minor particularities in technical terms and conceptualisation, there is virtually no difference as compared to other schools in the usage of the notion of sunna.
\end{abstract}

Keywords: hadith, Ibadhi, shari'a, Sunna, usul al-fiqh

Research on the Ibadhi (ibadi) madhhab, its history and representatives in East and West, the Mashariqah (mainly in Oman) and Magharibah (in today's Tunisia, Algeria and Libya), has flourished ever since Amr Ennami's seminal doctoral dissertation in 1971. Research on the Sunna as a legal source and on the hadith sciences in the Ibadhi madhhab is available; however, to our knowledge, there has been no attempt in Western studies of Islam to investigate the notion of sunna and its usages in Ibadhi writings from its beginnings to the present age. Recent contribtions are rather limited in scope or do not attempt to portray the madhhab in diversity.

This paper endeavours to trace the different usages of the concept of sunna in the Ibadhi literature in its different specializations: linguistics, usul al-fiqh, fiqh, and intersections with hadith, athar (narration; pl. athar) and sira (path, way; pl. siyar). It reflects the internal diversity of the madhhab as well as a development in time (but not in space, as there seems to be no difference in development between Ibadhi scholars in the East and West of the Islamic World). Given the nature of the subject matter, it is sometimes difficult to classify scholarly teachings exclusively into one of these categories, as they may fit into more than one. The following division therefore goes by the main focus, in the knowledge that textual fragments could sometimes be classified otherwise.

\section{Usages of the Notion Sunna in the Ibadhi Literature Linguistic Usage of the Term Sunna}

It is customary to introduce technical terms through their linguistic meaning. The intention here is to show some examples of the linguistic usage of the term sunna in the Ibadhi heritage in addition to the definitions and meanings given in the Quran, the Sunna and standard dictionaries. The term sunna (pl. sunan) is used in the Quran in the sense of tariqa (method). In Surat al-Nisa' (4:26), according to

\footnotetext{
${ }^{1}$ Ahmed Yahya Ahmed al-Kindi* (corresponding author), Ph.D., assistant professor at Department of Islamic Education, College of Education, Sultan Qaboos University, Khoudh 123, MUSCAT, Oman, email: abuyahya@squ.edu.om; Iman Anke Sandra Bouzenita, Ph.D., associate professor at Department of Islamic Education, College of Education, Sultan Qaboos University, Khoudh 123, MUSCAT, Oman, email: bouzenita@squ.edu.om.
} 
Ibn 'Atiyya, what is meant by sunan in this verse is "the methods, aspects and facets of something" (1982: 21/4; compare Surat al-Isra' 17:77).

The term sunna has been narrated with the same meaning of 'method' in the prophetic hadith, as in his statement:

Whoever introduces in Islam a good sunna, and it is followed after him, the same reward is recorded for him as for the one who follows it, without any of their [respective] rewards being reduced; and whoever introduces in Islam a bad sunna, and it is followed after him, the same burden is recorded for him as for the one who follows it, without any of their [respective] burdens being reduced.

As the focus here is on Ibadhi literature, it is most appropriate to start with the fourth century AH (11 ${ }^{\text {th }}$ c. CE) scholar Abu al-Mundhir al- Awtabi and his linguistic encyclopaedia Kitab al-ibana. AlAwtabi discusses a number of different meanings of the word sunna in the Arabic language, among them al-tariqa and al-sira: both may be rendered as 'method' or 'way'. Quoting broadly from Arabic literature, he mentions the synonyms al-wast (the middle) and al-jadda (the middle of the road). Sunna is what a person has done in terms of actions or 'laid down' as something to be followed (1999: 3/266). The Ibana mentions the term sunna in its positive linguistic meaning only (al-Kharusi 2014: 22ff). The eminent linguist Ibn Faris uses it this way: "The Sunna of the Messenger of Allah and his sira" (1990: 3/61).

It is apparent that these linguistic meanings of the term sunna are incorporated in their technical usages and concepts, as the linguistic meaning builds or forms the technical meanings; this is so as the Sunna in its reality expresses the methodology (tariqa) of the life of the Prophet Muhammad (pbuh). His sira (here: life) and tariqa (method) amount to the same meaning; he laid them down (sanna) for his community; and he asked them to let themselves be guided by it. As is expected, we find the mentioned linguistic usages, and sometimes a combination of linguistic and technical usages, in the Ibadhi sources; as the well-known faqih Abu al-Mu'thir al-Salt b. Khamis alKharusi (278AH/892CE) states:

Whoever does not abide by the Book of Allah and does not follow the Sunna of the Messenger of Allah (peace be upon him), or the established practice (sunna) of the Muslims is not a [suitable] Imam for the Muslims, but is rather an Imam for the unlawful rebels (bughat). The Imam in the religion (al-din) I mean here is not the one who gives the Friday sermon and makes supplications and awakens people's interest, but the Imam of the [Islamic] din is rather the one who knows the science of interpretation [of the Quran], and the Sunna of the Messenger (pbuh), according to the sunan of the Muslims and the traditions (athar) of the learned (al al-fadl) in the $\operatorname{din}$ (1996: 24; Kashif, 1986: 1/42ff).

Abu Bakr Ahmad b. 'Abd Allah b. Musa al-Kindi (557AH/1162CE) uses the expression in his Kitab al-ihtida", "and the sunna of the Muslims has been such (qad jarat bi-dhalika sunnat almuslimina)" (1985: 85). All the same, we may perceive its usage in the meaning of 'method' (tariqa), as in the expression of Abu Sa'id Muhammad b. Sa'id [al-Na'ibi] al-Kudami (fl. 272AH/886CE), who discusses the fiqh of aflaj (water channels), the Omani irrigation system: "It pleases me that he abides by (an yaqtafi) al-sunna al-madruka in cleaning the aflaj" (1985: 3/199). Elsewhere, in the chapter on the distribution of houses and wealth, he states, "humila cala al-sunnati al-madruka," (1985: 3/127) where he takes the word sunna to mean the followed and established practice, thereby 
coming closest to the fiqhi meaning of ${ }^{c}$ urf (custom), which meets an aspect of the linguistic meaning of the term sunna.

\section{Usuli Usage of the Term Sunna}

What is meant by the usuli usage of the notion of sunna is its treatment as legal evidence and a foundation relied upon in legislation. In this sense, the term sunna has been present ever since the beginning of the compilation of Ibadhi teachings.

The letter from Jabir b. Zayd (93AH/712CE) to 'Anifa reveals an emphasis on the importance of sunna. It reads:

I received your letter, in which you ask me to answer your question with what you can be assured of (tatma'inn ilayhi). This can only take place through Allah and His Sunna; it is only to be found in what people narrate from people [i.e., an authentic narration of the Sunna]. As to personal opinion ( $r a^{\prime} y$ ), with us, we are least likely to resort to it (wa amma min ra'yin cindana, fa nahnu fi dhalika anqasu ra'yan).

In the same letter, he writes:

Concerning what you mentioned of people who are led by an illiterate imam in prayer that requires recitation, when he reads only the Mother of the Book [i.e., Surat alFatiha] and he did not complete [it, i.e., the prayer]: is the prayer of the person who prayed behind him complete, or does he have to repeat his prayer? The answer to this is that he repeats his prayer, as he already contradicted the Sunna (fa-innahu qad khalafa al-sunna), and any matter in which the Sunna was contradicted is invalid (wa ma kana amrun khulifa fihi al-sunna naquda) (al-Ja'biri 2013: 48, 109).

In his letter to 'Abd al-Malik b. al-Muhallab, he responds to his previous detailed questions concerning menstruation and the waiting period (idda): "You ask how to deal with these cases if it is known that al-haqq [i.e., the Quran] and the Sunna have been contradicted. If any woman marries during her "idda, they [the couple] shall be separated" (al-Ja'biri 2013: 147). These examples reveal Jabir b. Zayd using the usuli notion of Sunna, as the answer of the Imam of the Madhhab clearly invokes and depicts resorting to the Sunna as a source of the specific legal rulings. Even more explicit may be the following dictum of Jabir with regard to the ruling on somebody who makes an unjust bequest (as part of a will and testament), "that the Wali or Imam of the Muslims returns it to [i.e., leads the issue to be resolved on the basis of] the Book of Allah and the Sunna of His Prophet (pbuh)." (al-Zawari n.d., 2). The chronological order demands reference to al-Rabi' b. Habib al-Farahidi al-Azdi (170 AH/ $787 \mathrm{CE}$ ) and his athar at this place. Answering the question whether the Friday congregational prayer could be performed behind al-Hajjaj b. Yusuf, al-Rabi`states:

[254] Al-Rabi from al-Damam [who] said: I came to Abu al-Shactha' on a Friday, and when al-Rawah came to him, he told me: Get up, so that we can go to the Friday prayer. I asked: Behind al-Hajjaj? He replied: Yes, as it is a congregational prayer and a sunna to be followed (qala na'am, fa-innaha salatun jami'a wa sunnatun muttaba'a) (Kahlan Al-Kharusi 2003:60) 
Abu cUbayda Muslim b.a. Karima al-Tamimi (145AH/763CE) underlines the insufficiency of any ra'y (here: legal opinion) or qiyas (legal analogy) to the two original sources (Quran and Sunna), when he comments on an unacceptable (refuted) qiyas: "This amounts to argumentation (jidal) and an analogy that is in contradiction to the Book of Allah and the Sunna of the Messenger of Allah (pbuh), and this is specifically forbidden." (n.d.).

Discussing the legal ruling on nabidh, an alcoholic drink made of dates, Abu 'Ubayda is quoted, on the authority of his student Abu al-Mucarrij: "The Messenger of Allah (s) has prohibited it, and whatever the Messenger of Allah prohibited haram" (Al-Khurasani 2006: 353; Ahmad al-Kharusi, 2014:70) The Mudawwanat Abi Ghanim (2nd c. H), one of the most important sources on Ibadhi fiqh, quotes the Basrian Ibn `Abd al-cAziz, a student of Jabir b. Zayd and prominent Ibadhi scholar of the second century $\mathrm{AH}$, on the same discussion of nabidh: "Nobody is bound more by al-athar and by reference to the Sunna than the learned faqih" (al-Khurasani, 2006:356ff; Ahmad al-Kharusi 2014: 31). The appendix to the Mudawanna states in Kitab Ibn Ibad in the chapter on "hiyyaza (seizure) and al-mawwat (waste land)": "Whatever the Prophet (pbuh) said is the truth, and the Sunna is more entitled to be followed if it is a sunna from the Prophet (pbuh); as for analogy, the truth that preceded it must not be annulled, as the truth is established of old (li-anna al-haqqa qadim), it is not annulled by what follows it" (al-Khurasani 2006: 572; Ahmad al-Kharusi 2014: 31). Along the same lines, Salim b. Dhakwan al-Hilali (fl. 101AH/720CE) confirms his following of the religious authorities (a'imma) preceding him on the basis of their superior knowledge of the Quran and the Sunna, stating:

Our ra'y (legal opinion) today follows their legal opinion in their days, and our interpretation of the Qur'an today follows their interpretation of the Qur'an in their days; we do not belong to those who claim that one can acquire as much knowledge of the Qur'an and the Sunna today as to achieve supremacy over them (Crone \& Zimmermann 2001: 132; Ennami: 2008: 133).

Ibn Dhakwan's letter is an important source as it may be considered among the earliest Ibadhi writings. It may be helpful to explain the term sira as it describes a particular literary genre. In the Omani Ibadhi context, a sira usually describes a doctrinal letter or manifesto ("pulpit manifesto" (Crone \& Zimmermann 2001: 23), to be read aloud to an audience. It is therefore not a biography, nor does it come under a fiqhi treatise. Siyar are, however, rich in references to dogmatic and fiqhi concepts (Crone \& Zimmermann 2001: 23; Al-Salmi 2001:12ff; Al-Salimi 2010; Al-Salimi 2009). The letter was written in a strongly political connotation. Usage of the term sunna, however, covers a wide range of meanings. In the fiqhi sense, Ibn Dhakwan states:

“...and we do not see that we should declare lawful a man's intercourse with his wife whom he married according to the Book of Allah and the Sunna of His Prophet, unless her [previous] husband had divorced her or he died and she completed the cidda of the divorced or widowed woman" (cf Crone \& Zimmermann 2001: 138)

In his discussion of the Azariqa, he writes: "And they disbelieved in rajm (stoning of the married adulterer), although the Messenger of Allah stoned a man from the tribe of Aslam, and the Sunna was established like this (wa madat bihi al-sunna)." (author's translation, cf Crone \& Zimmermann 2001: 102) Ibn Dhakwan's letter has frequent references to the term sunna, but also to sira or sabil as the 'way of the Muslims in the past'. Ibn Dhakwan admonishes one of the opponent groups, the Bad'iyya, requesting that "they fear Allah, and act according to the Sunnah of the Messenger of Allah, and that they make their affiliation on the basis of acting upon it [the Sunnah], 
even if they are weak in it (wa an yatawallaw'ala al-'amal biha wa in dacafu 'anha)" (Crone \& Zimmermann 2001: 140).

The 3rd century AH book entitled Ajwibat 'Ulama' Fazzan, containing scholarly correspondence between Ibadhi scholars in Basra and Libya, evidences the same usage. As is apparent from the letter of Jannaw b. Fata to Abu Sufyan 'Abd al-Qahhar b. Khalaf, nearing the end of his life he invites the addressee to another meeting for the purpose of discussion, memorization and gaining knowledge (al-tafaqquh) in the Quran and Sunna. Jannaw informs his scholarly friend that only those of his fatwas that are in accordance with the Book of Allah and the Sunna of his Prophet are to be followed (1991: 51). The term sunna is also referred to in the political sense or interchangeably with sira, as in Ibn Dhakwan's letter (Jannaw 1991: 69). Answering a legal question regarding a father who gives away all his possessions to his son, who in turn sells them, he writes, denying the legitimacy of that action: "And whatever the Sunna has been contradicted by, finds its rebuttal (naqduhu) in the Sunna (wa kullu ma khulafa fihi al-sunnatu fi al-sunnati naqduhu)." (Jannaw, 1991:78)

While it is obvious in the terminology of Jabir, Abu 'Ubayda, Ibn Dhakwan and Jannaw b. Fata, that sunna describes the Sunna of the Messenger as a legal source, we find that Abu Abd Allah Muhammad b. Mahbub al-Qurashi al-Ruhayli (260 AH/874 CE), in his treatise "Abridged Chapters from the Sunna" (Abwab min al-sunnati mukhtasara), uses the technical term sunna in a much broader sense. The book treats different topics in fiqh; chapters typically start with "The sunna in ... " (al-sunnatu fi ... ). For each legal question it refers to specific evidences from the Quran, the prophetic hadith, and ra'y. Ibn Mahbub may even refer to something as established by the Quran or by ijtihad or ra'y as sunna. The editor comments on Ibn Mahbub's use of the term sunna:

The degree to which he extends the usage of the technical term sunna is striking, and his consideration that everything that is evidenced in Islamic law through the Book, or hadith, or the consensus of the community, or what has been derived from a clear cut (qat'i) evidence is from the Sunna, therefore the book is called "Abridged Chapters from the Sunna" (Warjalani 2009: 216).

Mustafa Baju has alluded to this particular broadened usage of Sunnah in Ibn Mahbub's writings (2002). The treatises of his son, Abu al-Mundhir Bashir b. Muhammad b. al-Ruhayli (d. ca. 290AH/904CE) (Nasir and Mubarak, 2006:1/254 ff), seem more refined from the usuli point of view. He is the author of Kitab al-Rasf (The Book of Alignment), K. al-Muharaba (The Book of Warfare) and a sira. Mention of sunna is made according to the literary genre, as we will see below. Kitab al-Rasf, written probably between 260 and $270 \mathrm{AH}$, contains discussions on several points of view that are distinctive of the Ibadhi community at the time. The editors suggest that the different topics originally represented various lectures, collected and abridged by a student (al-Salimi and Madelung, 2011: viii). Interestingly, the author presents a distinctive Mutazilite approach, whereas the Omani Ibadhi scholarly community was traditionalist (al-Salimi \& Madelung 2011: vii; Al Salimi 2015: 56). The book contains one chapter in particular that may illuminate the notion of sunna at the time of composition in the Ibadhi community. It therefore deserves thorough attention.

In the chapter entitled "Bab al-Sunna", Ibn Mahbub states that the Sunna of the Messenger of Allah has two divisions, farida and fadila. Whereas the fard is obligatory to be carried out (lazim ficluhu) and expels from the community of believers the one who abandons it, the nafl does not influence the status of the one who does not carry it out. He further explains that farida is divided 
into wajib 'ayn and wajib kifaya, conceptually, without mentioning the technical terms (al-Salimi \& Madelung 2011: 19).

He also explains the function of the Sunna with regard to the Quran, the Sunna as establishing legal rulings (al-rajm) independently of the Quran (al-Salimi \& Madelung 2011: 19), that the Sunna can abrogate legal rulings of the Quran (as in la wasiyyata li-warith). The treatise also provides examples for sunan al-nafl (like the two supererogatory units of prayer at fajr), and fara'id al-sunan (e.g., istinja' and khitan) (ibid, 20ff). He further adds examples for what usuli scholars usually summarize under sunna mu'akkada and sunna qawliyya wa fi'liyya, verbal and actual sunna, as well as the sunna that is particular to the Prophet (as in continuous fasting) (Ibid, 21).

While the chapter gives the appearance of lecture notes to be presented to an educated audience, it is apparent that the author summarises the most important concepts that are commonly discussed by scholars of usul al-fiqh under the topic of sunna, but without using the terminology common today. This may serve as evidence that, although the conceptualization was there, the terminology was not fixed at the time. In his sira (Sirat Bashir fi al-hadath al-waqi' bi-'Uman), which represents an evaluation of the political events of his time within a fiqhi framework, he comments within his discussion on the discharge of Imam al-Salt, an event of the third century that occupied Ibadhi scholars in many volumes, that it does not "take the place of an obligation (mafrud) from the Book of Allah or the Sunna or ijma '(consensus)" (al-Salimi \& Madelung 2011: 66). He also states:

No evidence is weaker and made feebler ( $a w h a)$ than a pretense ( $d a^{c} w a$, a claim) that does not have certain proof (burhan) or evidence (dalil) in the Book of Allah cazza wa jalla and the Sunna of His Prophet (pbuh) [cala tahqiqiha] (Ibid, 64).

Other of his statements may be even more precise in the usuli sense, such as the one mentioned in the "Chapter on names and verdicts" (bab fi al-asma' wa al-ahkam): "Through the Book of Allah and the Sunna of His Messenger (pbuh) and the consensus (ijmac) of the Muslims, names are established and rulings result (tathbut al-asma' wa tujra al-ahkam)." (Ibid, 18 \& al-Ruhayli n.d., 252f)

The usuli usage of the term sunna becomes even clearer in the writings of Ibn Baraka and Salama b. Muslim al- Awtabi (Al-Battashi, 2004:1/350 ff) (both $4^{\text {th }}$ C. AH/10 th $C$. CE), pointing at a development through time. Ibn Baraka refers to and discusses the legal views of the representatives of other legal schools, such as al-Shafi' $i$ and Abu Hanifa and their disciples. His treatment of the Sunna as a legal notion uses a very mature terminology with no recognizable difference from that of other usuli scholars of his era. This becomes obvious, for instance, in his discussion on the abrogation of the Quran by the Sunnah and the Sunnah by the Quran (Ibn Barakah, n.d.: 1/42ff). Discussing Abu Hanifa's view on the free woman covering her head and feet during prayer, he states:

They [Abu Hanifa and his disciples] permitted taqlid (imitation), although it is not permissible with the presence of authentic evidence (dalil sahih) from the Book, the Sunna and $i j m a c^{c}$ or rational evidence (hujjat al-caql) (Ibn Barakah, n.d.:1/543).

Also, the chapter entitled 'Babun fi shay'in min al-usul' (Ibn Barakah n.d.: 3/7-20) has numerous references to the Sunnah as a source of law. Al-Awtabi's Kitab al-Dhiya' is replete with references to the Sunna. In his "Chapter on things related to usul" (bab fi shay'in min al-usul), he states, "Truth (al-haqq) is known through four aspects (awjah): the Book, the Sunna, ijma' and rational evidence; and there is said to be a fifth, namely tawatur al-akhbar" (1990: 3/9).

In spite of the early appearance of the usuli notion of the term sunna in the Ibadhi madhhab, the appearance of a definition in the literature dates relatively late. Apparently, the first extant 
technical definition is by Badr al-Din Ahmad b. Sa'id Abu al-Abbas al-Shammakhi (928AH/1522CE) who explained that the Sunna in the technical terminology of the usuli scholars is "what can be traced back to (ma sadara 'an) the Prophet (pbuh) other than the Quran in speech, action or tacit approval." (1989: 92). Two centuries later, Jerban scholar al-Talati (1187AH/1747CE) provides this definition: "The Sunna comprises Muhammad's statements, his actions, aspiration and resolve, and his tacit approval." (n. d.: § waw/40). Another two centuries later, the eminent Omani scholar and reformer Nur al-Din 'Abd Allah b. Humayd b. Sallum al-Salimi (1332AH/1914CE) (Nasir \& Mubarak, 2006: $271 \mathrm{ff}$ ) states that the Sunna in the terminology of scholars of hadith and usul is "What can be traced back to (ma sadara can) the Prophet other than the Quran, in speech, action or tacit approval." (2010: 2/2). The contemporary scholar Ibrahim b. Ahmad al-Kindi approves of the same definition with the addition of "in other than natural things" (1998: 117). The definition of the contemporary scholar Sa'id b. Mabruk al-Qanubi is the most accurate: "Whatever has been narrated from the Prophet (pbuh) by way of speech, action or tacit approval, and an Islamic ruling has been extracted from it." He also specified: "[Any] attribute [of the Prophet] is, and this is the most correct, also included if an Islamic verdict has been derived from it" (n.d.: 1).

\section{Fiqhi Usage of the Term Sunna}

In fiqh, the term sunna is generally used to designate recommended actions and is therefore synonymous with nafila or manduba. Some representatives of the Ibadhi school are very diligent in distinguishing the concept of an obligation (wajib or farida) as established by the prophetic Sunna (often referred to as sunna wajiba), from a recommended action (sometimes referred to as fadila) evidenced by the same.In his letter to cUthman b. Yasar, Jabir b. Zayd writes about male circumcision that it is sunna wajiba and thus it is impermissible to leave it:

Concerning what you wrote to me, asking about the slave (al-mamluk), does he pray although he has not been circumcised? Circumcision is a sunna wajiba among the Muslims, and it is not permissible (la yanbaghi) to leave it. And we discourage (nakrah) that you should leave a slave of yours uncircumcised, and he should not pray until he has been circumcised (al-Ja'biri 2013:78; see Ennami 2008:132; Boulrawah 2006: 2/1177).

Additional relevant material can be found in Jabir's responses (Min jawabat Jabir); asked about al-qunut (a particular form of supplication) in salat al-ghadat wa al-witr, he answered, "This is something that people have introduced; it did not exist in the time of the Messenger of Allah, and not in salat al-ghadat, nor in the time of the Caliphs after him." (Sa id al-Kharusi 1984: 74) Asked about a couple who do not find water to perform the major ablution ( $g h u s l$ ) from post-coital ritual impurity (janaba), he refers to the practice of the Prophet:

Yes, they perform dry ablution (tayammum) with clean, dry sand or soil (sa'id tayyib), and they wipe [their hands and faces] with it. If they find water, they perform ghusl with it. The Messenger of Allah (s) performed ablution (wudhu') in this way (Sa'id alKharusi 1984: 14). 
It is documented in the letter of Jabir b. Zayd (93 AH / $712 \mathrm{CE}$ ), addressed to al-Harith b. Amru, one of the early $d u^{c} a t$ (propagators) of the Ibadhi movement and followers of Jabir in Kufa who became prominent during the Caliphate of `Umar b. `Abd al-`Aziz (al-Ja`biri 2013: 58):

Concerning what you mentioned about a man who prays al-maghrib, al-cisha' and alsubh and does not recite anything of the Quran, it is preferable to me (ahabbu ilayya) that he repeats his prayer and recites in it, as he has deviated from the Sunna in it unless he be illiterate or his language is unclear, as Allah does not oblige a person above his ability (al-Ja'biri 2013: 48, 100; Ennami 2008: $132 \mathrm{ff.})$

In the same letter, he mentions:

With regard to your question, when the Imam leads people in the obligatory prayer, but he left out bowing $\left(a l-r u k u^{c}\right)$ and people followed him in this, it is better for them to repeat that respective prayer, because they contradicted the Sunna in doing so (AlJa'biri 2013: 48, 100; compare Sa id al-Kharusi, 1984: 45).

When al-Rabi b. Habib al-Farahidi al-Azdi (170AH/787CE) was asked whether rinsing the mouth (madmada) and the nose (istinshaq) during ablution, were obligatory (faridatani), he replied, "They are from the Sunna (huma min al-sunna)", thereby stressing their obligatoriness (n.d., MS no. B47: 178). In the context of the legal rules of prayer, the Mudawwana al-Kubra differentiates:

As to knowledge (al- 'ilm), it has three aspects (awjah): that you know to differentiate between farida and sunna, as prayer is not allowed without this; that you know the farida from the sunna in ablution, as this belongs to completing the prayer; and that you know Satan's deceit, and be aware of it as much as you can (al-Khurasani 2007: $1 / 245)$.

Obviously, sunna is being used in the sense of a recommended action in contrast to farida, the obligatory legal ruling. Similar expressions are recurrent in the early Ibadhi contributions. The letter of Abu Ayyub Wa'il b. Ayyub al-Hadrami: (alive in 192AH/808CE), for instance, is replete with examples of the term sunna (and sira, see below), covering the entire spectrum of its meanings, including the Sunna as a source of law after the Quran and sunna as recommended action: "... and to give zakat (zakat) for the known categories according to the obligation of Allah and the Sunna of his Prophet (ala faridat Allah wa sunnati Rasulihi)" (Kashif 1986: 2/48); "and marriage according to farida and Sunna" (Ibid, 2/49); "divorce in the presence of witnesses and the idda according to the Sunna of divorce" (Ibid, 2/49).

Maybe the first attempt to define the term with more terminological accuracy in writing was by Bashir b. Muhammad b. Mahbub al-Ruhayli (290AH/904CE) and Abu Hafs 'Amrus b. Fath alMasakini (283AH/897CE) in their classification of what sunna refers to. 'Amrus, in the chapter on zakat al-fitr, divides sunna into two: a sunna in something that is not obligatory (sunna fi ghayr farida), wherein undertaking it is a fadila and not undertaking it is not a reprehensible mistake; and sunna in an obligatory action, wherein undertaking it amounts to right guidance (huda), not undertaking it is misguidance (dalala) (al-Masakini 1999: 102). 'Amrus b. Fath also invokes the notion of sunna wajiba, as explained above: "The Messenger of Allah (s) sanna madmada and istinshaq, and they are both wajib: it is not permissible to avoid performing them and the prayer is not lawful without them both." (Ibid, 92). He refers to the Sunna of the Messenger of Allah twice, 
explaining the rulings regarding amputating the hand (Ibid, 128), and regarding the call to prayer (adhan): "ajma'a al-nasu annahu min sunnati rasuli Llahi calayhi al-salam wa-ikhtalafu fihi" (Ibid, 156), where the mentioned difference of opinion refers to the times of adhan and iqamah. Bashir alRuhayli states:

The dictum (al-qawl) with regard to the Sunna from the Messenger of Allah (pbuh) is that it has two aspects: obligatory (farida) and recommended (fadila); al-fard is binding to be undertaken, and whoever abandons it has abandoned belief (al-iman). As to what is recommended ( $a l$-nafl), whoever does not fulfil it is not sinful, and acting upon it is not binding (al-Ruhayli n.d. 253; al-Salimi \& Madelung 2011: 19).

He then completes the description of his classification with an explanation of further rulings for every division:

Whatever is obligatory (fard) to be undertaken, is obligatory to be commanded, and it is obligatory to forbid not undertaking it after the evidence is established. Whoever left this action needs to make up for it for as long as [the period during which] he did not worship with it (ma lam yakun mutadayyinan bihi); there is no room to excuse ignorance of it, and ignorance of it is not excusable if he performs it as something Allah has made obligatory for him; it is also not excusable not to know the time in which the obligation needs to be fulfilled, or to make a mistake here. Whatever is recommended (nafl), the undertaking of this action as well as the command to do it is recommended, as is the prohibition (al-nahiy) against not doing it (al-Ruhayli, n.d. 253; al-Salimi \& Madelung 2011: 19).

Ibn Mahbub's Kitab al-Muharaba, in its essence a fiqhi treatise, offers more material on the fiqhi usage of the term, as in his statements: "The Messenger of Allah (pbuh) established the sunna that there is no war prior to the call [to Islam]" ("wa sanna Rasul Allah (s) anna la harba illa ba'da alda'wah") (al-Salimi and Madelung, 2011:36); about the treatment of the Magians (al-Majus), he states: "And He [Allah] gave them [Magians] the same judgment concerning the acceptance of jizya, through the Sunna of the Messenger of Allah (pbuh)." ("wa alhaqahum bi-hukmihim fi qabd al-jizya minhum bi-sunnatin 'an rasuli Allah (s)" (Al-Salimi and Madelung, 2011:37). Other examples are abundant; "fa amma al-dalil 'ala luzumi dhalika wa farduhu min kitab Allah wa sunnati Rasulihi, fa...". (Ibid, 39); "wa amma ma kana fi dhalika min sunnat al-Rasul (s) (Ibid, 40); "li-annahu lam yukhrijhu min cumum al-amr bihi lahum bi-ayat al-kitab hujja wa la bayyan fi al-sunna" (Ibid, 43). He also frequently uses the term jarat al-sunna (the sunna has established...)". On the apostate, he states: "wa jarat al-sunna an la yuqtalu illa ba'da al-istitaba lahum" (Al-Ruhayli, n.d.: 265; compare Al-Salimi and Madelung, 2011: 38). Other examples are "wa jarat bihi al-sunna fihim" (Al-Ruhayli, n.d.: 270; AlSalimi \& Madelung, 2011: 44); "wa jarat bihi al-sunna" (Ibid, 44) and "ma jarat bihi al-sunna" (Ibid, 46).

The third century AH scholar and Qadi from Nizwa, Muhammad b. al-Hawari b. 'Uthman Abu al-Hawari (d. $272 \mathrm{AH} / 886 \mathrm{CE}$ ) (Al-Battashi 2004: 1/275f) follows the typology of the two preceding scholars in his discussion of the status of a person who does not perform a given sunna. Again, one category of sunna constitutes 'an obligation' (farida), the undertaking of which is guidance (huda), whereas leaving it for the sake of something else constitutes an error (khati'a) (n.d. 135ff). It seems that what is meant by tarik al-fadila, the one who leaves what is recommended for something else 
(ila ghayriha), means to leave it for what is contrary to it. Maybe this is what he has in mind when he later speaks of "sunna makruha". (Abu al-Hawari n.d. $153 \mathrm{ff}$.). In the same author's sira to the people of Hadramawt in Al-siyar wa al-jawabat, (1986: 1/338 ff.), he mentions that the Quran can abrogate the Quran, the Sunna can abrogate the Sunna, and the last revelation of the Book (the Quran) and the Sunna should be taken [to be followed]; the Sunna can also abrogate the Book, as the Sunna is a verification (tasdiq) of the Book (Kashif 1986: 1/361 ff).

In the seventh century AH, Abu 'Abd Allah al-Asamm 'Uthman b. Abi 'Abd Allah al-Azri (d. 631/1137) uses the term sunna in its entire variety of meanings. In contrast to al-Awtabi (see above), he mentions both the positive and negative linguistic meaning. Al-Asamm introduces his chapter on Sunnat al-Kifaya with the prophetic hadith ("man sanna sunnatan hasanatan ...) (1984: 2/15) and a linguistic explanation of the term: the term sunna in the religion being used because it represents a method (tariqa) and way (masira) as well as aspects (wujuh), and indicators (calama) and representation (rasm) from the prophets, that is taken as guidance (yuqtada biha). He concludes: “. . . and every sunna that agrees with the Book is a Sunna of the Messenger of Allah (pbuh), and whatever contradicts the Book is an innovation (bid'a) because the Book and the Sunna agree and support each other (muttafiqan maqrunan) (Ibid, 2/17). He goes on to explain that all sunan fara'id belong to one of three kinds: an explanation to an obligation communicated in the Quran, an abrogation from the Prophet, or additional sunan (sunan zada Allahu tacala) legislated through the tongue of the Prophet (Ibid, 2/17). The examples given for this third division (stoning for the muhsin as legislated by the Prophet) (Ibid, 2/16ff), show that this division of sunna represents legislation independent from the Quran (sunnah mustaqilla) (Ahmad al-Kharusi 2014: 228). After detailed explanation of the three categories, he concludes:

Whatever comes from him (pbuh) is a Sunna, and whatever comes from a'immat alcadl is an athar that needs to be followed, and his (pbuh) Sunna consists of what is obligation (farida) and what is sunna [here as contrasted to the obligation in the meaning of recommended] and education ( $\left.t a^{\prime} d i b\right)$ [i.e., what comes under sunan aladab (educational sunna)]" (al-Asamm 1984: 2/17).

It seems that this understanding is closest to the designation of hadith (al-dalala alhadithiyya), as the scholars of hadith often focus on the generality of following the Sunna of the Prophet in every aspect of life. Al-Asamm's subsequent chapter thematises "sunan al-insan" (i.e., sunan al-fitra), thereby completing a wide range of different meanings of sunna (Ibid, 2/18). What the scholars we quoted previously meant by wajib or fard (obligatory) is a prophetic sunna establishing the wajib or fard; the term fadila, on the other hand, clearly designates a recommended action. The scholar Ibn Jami` Abu Hafs `Amru b. Jami ( $7^{\text {th }}$ c. AH/12 ${ }^{\text {th }}$ c. CE) is probably more explicit in his usage of his terminology when he divides the sunna into ". . two aspects: What the Prophet (pbuh) did but did not command others to do: this is a supererogatory action (nafila); acting upon it is a recommendation (fadila), and no punishment is incurred for not performing it; and the Sunna which he performed and commanded (others) to perform: acting upon it is an obligation and punishment incurred for not performing it." (2000:45ff).

Abu Sitta Muhammad b. 'Umar al-Sadwikshi al-Qasbi (d. 1088AH/1678AD), in his commentary on Shammakhi's K. mukhtasar al- 'adl wa al-insaffi usul al-fiqh, remarks on Shammakhi's treatment of al-mandub (the recommended action) as one of the divisions of the Islamic ruling, that it would have been appropriate to say, where he briefly introduced al-mandub as something that is not wajib and incurs a reward for acting upon it: "All of al-mandub, al-mustahabb, al-tatawwu' and sunna are synonyms; maybe he means that he was not exposed to this, as the dictum (kalam) of our 
companions in the books of fiqh leaves the impression of a lack of synonymity." (n.d.:73). In his Hashiyat Kitab al-Wad', Abu Sitta combines the two expressions, stating that istitaba (asking somebody to repent) is wajib as well as sunna; concluding that it is a sunna wajiba (n.d.:146). The first fiqhi definition of the term sunna seems to go back to al-Shammakhi, who writes:

As to the technical meaning according to the fuqaha' (scholars of fiqh), it [sunna] comes to the meaning of mandub or cibadat nafila (supererogatory acts of worship) and whatever is not obligatory (wajib), or what is opposed to an illicit innovation (bid’a).” (1989:92).

We find an explanation of the sunna mu'akkada with 'Amru al-Talati's definition as "whatever is requested in a strong manner and does not amount to jazm (absoluteness)" (n.d.: 72). Nur al-Din Al-Salimi abbreviates Shammakhi's definition: "It [sunna] means recommended actions." (2010: 2/2). The definitions of al-Shammakhi and al-Salimi entail what is supererogatory (nafl), recommended (mandub) or not obligatory (ghayr wajib), but there may be some need of discussion concerning the confinement of the concept to acts of worship, and there may be no need to include the idea of bid'a as al-Shammakhi did. 'Amru al-Talati has a more general definition of the term, as he mentioned that sunna in the usage of specialists of Islamic law designates "the legal rulings with which the Noble Prophet (pbuh) has been sent." (n.d., MS 49:36) This generalized definition incorporates all five categories of Islamic legal rulings - the obligation (al-wajib), the recommended action (al-mandub), the optional (al-mubah), the discouraged (al-makruh) and the prohibited (alharam), insofar as they are all revealed through the prophetic Sunna-in the sense of the source of law. The definition of the contemporary scholar Ibrahim b. Ahmad al-Kindi carries the same generalization; the Sunna is, according to him,

Whatever has been established in the authority of (ma thabuta can) the Prophet (pbuh) other than an obligation (iftirad or wujub) and what corresponds to the obligation (al-wajib) and others of the five divisions of legal rulings), as well as what opposes innovation (bidca) (Ibrahim Al-Kindi1998: 120).

The definition suggested by the contemporary Omani scholar Sa'id b. Mabruk al-Qanubi tends more to the fiqhi usage: "whatever carries a reward with it when undertaken, and a reprimand, not a punishment when it is not done" (n.d.: 1). It seems that this technical concept of sunna wajiba, an obligation as established through an evidence in the prophetic Sunna, has been prevalent in most Ibadhi writings scrutinized here. The distinction between farida and fadila with regard to the Sunna, as used by Bashir b. Muhammad, indicates the same conceptual distinction using slightly different terminology. It may indeed be claimed that the Ibadhi School has this terminological subdivision of the Sunna as a unique feature. The contemporary Encyclopaedia of Ibadhi Terminology (Mu jam mustalahat al-ibadiyya) mentions that Ibadhi sources divide sunna into sunna wajiba and sunna mustahabba:

The sunna wajiba is more emphasized (awkad) than the mustahabba, and it is not permissible to abandon it: such as tasmiya, washing the hands, madmada and istinshaq in wudu', and reciting the tahiyyat in prayer. Al-Qutub Atfayyish said: Prayer is not valid if it is left, even unintentionally, whereas leaving the other [kind of sunna] is permitted if unintentional (2012: 1/472). 
The Ibadiyya sees the contradiction to a sunna mustahabba as an impermissible matter, if it is accompanied by the intention to contradict and move away from following the Messenger of Allah (Ibid).

\section{The Notion of Sunna and Its Intersections with Hadith, Athar and Sira}

This chapter will not focus on the pure hadith sciences or the formal transmission of hadith in the madhhab. More interesting to us are the intersections of the synonymous usage of sunna as prophetic hadith, athar from the generation of Companions (Sahaba); and the synonymous usage of sunna and sira in Ibadhi writings. Some scholars of hadith have broadened the usage of the term sunna to comprise the entire life of the Prophet, more so than the scholars of fiqh and usul al-fiqh. The scholars of hadith usually define "the Sunna" comprehensively as the statements, actions and tacit approval of the Prophet (pbuh), as well as his ethical and physical traits. They also include his sira; some use the term Sunna to designate all of the hadith, the khabar (narration) and the athar, or even what has been reported about the Companions or the Successors (Abu Shabha, n.d. 15-17). The following paragraphs attempt to shed some light on how these concepts are reflected in chosen examples of the Ibadhi heritage through the ages.

Imam Jabir is quoted with the statement: hakadha al-sunna (this is the Sunna): "It is not acceptable (la yaslah) for a woman to marry except with the permission of her guardian (wali), and her guardian may not marry her [to anyone] except with her permission; and this is the Sunna." (Sa id Al-Kharusi, n.d.129). There are formal narrations of hadith (on the authority of Jabir), as in paragraph 222 (Ibid, 51), as well as references to prophetic hadith introduced by "balaghana" or "qala al-nabi" (Ibid, 130, 132, 134, 148). Other references are to hadith and athar from "Umar b. al-Khattab (Ibid, 131), and the practice of 'Umar (Ibid, 160). The distinctions in the book are clear in that they give priority to the prophetic Sunna and distinguish between hadith, athar and the practice of the Companions. The way of referencing is typical for the period, as comparison with contemporary treatises shows (Bouzenita 2001: 144-168).

There is good reason at this stage to discuss the contribution made by al-Rabic $b$. Habib to the usage of sunna in the Ibadhi legacy. Al-Rabi' authored one of the earliest works on Ibadhi fiqh, the Athar. His Musnad is to date one of the most important reference works on hadith for the Ibadhi madhhab. As he was a faqih and a muhaddith, an analysis of his usage of and reference to sunna and his use of hadith in his work on fiqh may be insightful as to the priority of the prophetic Sunna and the terminological introduction of the concepts. As the thorough analysis of Kahlan al-Kharusi (2003) has shown, the work clearly shows a "paucity of technical terms from either fiqh or usul-fiqh" (Ibid, 139), an indicator that the compilation of the work preceded the usage of such terms. However, conceptual distinction between the concepts of prophetic Sunna, athar, and 'amal (practice) of the Companions is clearly present, as was typical for other works of the same period. As comparable to other famous scholars who lived at the turn of the first/second century AH, the reference to sunnah in their fiqh dicta does not usually mention formal chains of narration (isnad), although these were known to them as evident by their hadith compilations. The Athar clearly state the authoritative status of the sunnah in several aspects, though the technical term 'sunnah' is only mentioned once (Ibid, 60). In conclusion, Kahlan Al-Kharusi emphasizes his surprise with regard to the similarity of Ibadhi fiqh to Sunni fiqh: "There is no single legal opinion of the early Ibadi authorities that is invented or irregular or contradicting the fiqh of mainstream Muslims" (Ibid, 175), and we may add, the similarity reference to the notion of sunnah in its different aspects and conceptualizations.

As Kharusi has pointed out, Rabic's "attitude to the Sunna and Hadith is articulated in a short, though significant statement in tradition [238]", and he cites an athar from al-Rabic on nabidh very

htpps://doi.org/10.24035/ijit.14.2018.001 
similar to the verdict (above-mentioned) of Abu 'Ubayda: "The Messenger of Allah prohibited it, and what the Messenger of Allah prohibited is haram (naha anhu rasul Allah, wa ma naha ${ }^{c}$ anhu rasul Allahi fahuwa haram)." (Ibid, 58). Kharusi emphasises that "many of his opinions are based on prophetic traditions" (Ibid, 169) and at least one reference is explicitly identified as a hadith: "[315] On the authority of 'Ammara from Habib, who said: I heard Damam b. al-Sa'ib say: The Messenger of Allah (s) prohibited renting earth and water. (sami'tu Jabir b. Zayd yaqulu: naha Rasul Allah 'an kira' al-ard wa kira' al-ma')" (Ibid, 69; Sacid al-Kharusi, 1984:112). The discussion of the marriage of minors refers to the practice of Abu Bakr al-Siddiq as dictum of the Kufiyans:

[148] Al-Rabi ' 'an Damam 'an Abi al-Sha 'tha', that he did not consider (la yara) the marriage of minors at all, until they become adults and can take decisions (wa yasta'mira); the Kufiyans say: If the father has concluded the marriage, it is permissible (ja'iz), and Abu Bakr al-Siddiq married off 'A'isha (may Allah be pleased with both) (Kahlan Al Kharusi, 43ff).

In another instance, the practice of 'Umar b. 'Abd al-Aziz is referred to. The following statements of Abu 'Ubayda, in the next generation, may illustrate the broadening in the usage of the term sunna:

The Imam of the Muslim is the Quran, and his guide (dalil) is the Sunna of the Prophet (pbuh); he [the Muslim] does not like but what Allah and his Messenger like, and he does not detest but what Allah and His Messenger detest. (Abu 'Ubayda, n.d.: 7 verso)

There is documentation for the term madat al-sunna in the narration of Imam al-Aflah, the third Rustumid Imam (d. $240 \mathrm{AH} / 872 \mathrm{CE}$ ) from al-Hasan b. a. al-Husayn: "The sunna has established (madat al-sunna) that the traveller shortens his prayer in a country he lives in, even if he lives there for ten years, as long as he has not taken it as his homeland (watan)" (Ahmad al-Kharusi 2014: 43). The literary legacy also gives insight into the interchangeable usage of the term sunna with sira. In his criticism on diverging groups, Ibn Dhakwan refers to the practice of the Prophet to kill Muslims (mimman yastaqbilu al-qiblata) only where the law demands it, and that he never declared their property to be booty, enslaved their women, or deprived their inheritors of their rights, "... and this was the sira of the Messenger of Allah regarding Muslims who went astray, and his Sunna which he laid down. (fa-kanat hadhihi siratu Rasul Allah fi al-muhdithina min al al-qiblati wa sunnatuhu allati sanna fihim)." (Crone \& Zimmermann 2001: 72). He advises, "Hold fast to the good path and the known sira in Islam that the Prophet of Allah (pbuh) and the awliya' of Allah have taken." (Ibid, 48) Usage of the term sira in the sense of an established practice recurs in his letter (Ibid, 112, 114, 122). The usage is also evident in the writing of Abu Ayyub Wa'il b. Ayyub al-Hadrami: (fl. 192 AH/808 CE). In a sirah that may have been sent to Imam al-Julanda in Oman (al-Salaymi 1996: 114), he says:

This is the sira of the Prophet of Allah (pbuh) with the adherents of these religions, and the just a'imma followed it after him with a complete and established Sunna (bisunnatin tammatin madiyatin thabita) in the din that the Caliphs of Allah on His earth implemented, in fulfilment of His right they do not contradict it, nor do they transgress it; and you will not find any change (tabdil) for the Sunna of Allah (Kashif 1986: 2/57). 
He also mentions, using the term sira as the established practice of the Prophet (pbuh):

And it was the sira of the Messenger of Allah with regard to the rebels that they are to be fought due to what they introduced with their rebellion [...] and it was his sira regarding Jews, Christians and Magians to call them to what they find in the Book of Allah [...] (Kashif, 1986: 2/56).

Wa'il also refers to the Sunna of the Prophet and practices of the Companions as established by narrations: ". . . and the prohibition of usury (al-riba) in adcafan mudacafan and to leave whatever is doubtful in this context and what has not been established by a Sunna or athar" (Kashif 1986: 2/52) sometimes in a political connotation: "... and to abide by the sunan (established practices) of justice and the narrations (athar) of the imams of guidance" (Ibid, 2/50). He also writes, "... and this is the Sunna, and whosoever is disobedient to Allah will never find a change in the Sunna of Allah." (Ibid, 2/48). Similarly, Hilal b. 'Atiyya al-Khurasani (134 AH/751 CE) uses the term sirat Rasul Allah in the meaning of sunna, contrasting the correct sira of the Prophet and the believers against the siyar of his opponents, which, according to him, resembles the sira of the Arab polytheists in part, of the People of the Scripture in part, and that of the believers in part (Hilal Al-Khurasani n.d. 79). Furthermore, he comments on the group of Kharijites who set the Muslims (ahl al-qibla) on the same footing as those in a state of war with the Muslims (ahl al-harb):

They contradict the sira of the Prophet of Allah (s) regarding the polytheists (al alawthan) and they so declared lawful [to take] from them what Allah has forbidden them [the Kharijites] of prohibited lives, intercourse and possessions (wa-istahallu bi-dhalika minhum ma harrama Allahu 'alayhim min al-dima' al-haram wa al-furuj alharam wa al-amwal al-haram) (Ibid, n.d.: 82).

Hilal's letter mentions the exemplary conduct of Abu Bakr and cUmar in chapters entitled "sirat Abi Bakr al-Siddiq" (Ibid, 66) and "sirat 'Umar b. al-Khattab" (Ibid, 67); under the latter, it states, “...wa iqtada bi-sunnati Rasuli Allah wa Abi Bakr..." (Ibid, 67). Suffice it to refer to the mentioning of the sunna in his letter that is commensurate with the other mentioned sources to complete the picture: "Fa-farida al-fara'id wa hadda al-hudud wa sanna al-sunan wa farida al-salawat" (Ibid, 65). "wa nas'alu Allaha sabilahu wa camalahu wa ittiba'an li-sunnatihi (Ibid, 66); "wa ma lam yujad fi kitab Allahi lahu athar fa-bi-l-sunnati Rasuli -llah al-ma'rufah fi asli al-ahdath wa ahli al-nifaq wa ma lam yakun fihi hukm fi kitab Allah wa la fi sunnati Rasuli -llah calayhi al-salam fa-atharun min ahli al-huda min awa'il al-muslimina alladhina ankaru awwala al-hadath wa saru fihi fa-halal Allah halal wa haramuhu haram ila yawm il-qiyamah" (Ibid 65, 83).

Amrus b. Fath al-Masakini, in the context of his differentiation between polytheist (mushrik), hypocrite (munafiq) and Muslim, and his criticism of enslaving fellow Muslims and taking their possessions as booty (as carried out by some groups such as the Azariqa and Najdat) - a common theme in Ibadhi treatises of the time-confirms this meaning when he links it with the idea of following the established way (al-sira al-ma'rufa), stating: "The Prophet of Allah (pbuh) did this in his well-known sira, the believers followed it when they were afflicted, and we used to follow it and did not introduce into it any innovation." (n.d.62). He reiterates this in the context of the treatment of polytheists (mushrikun): "wa bayyanna al-sirata fi kulli milla (Ibid, 64). The same approach (sunna as the Sunna of the Prophet, Abu Bakr and cUmar), is evident from other writings, like the Sira of Shabib b. 'Atiyya al-'Umani (fl. late $1^{\text {st }}$ - early $2^{\text {nd }}$ c. AH) (Kashif 1986: 1/346). It may therefore rightly be stated that it is part and parcel of the Omani Ibadhi sira genre of the time. We will find mention of 
the sunna of Abu Bakr or 'Umar, or the mention of both together, from the days of the first Ibadhi compilations, such as in Sirat Ibn Dhakwan, and maybe the following expression is the best testament to this:

Allah revealed the book to the Messenger of Allah (pbuh), and explained it to him through the sunan; after him came Abu Bakr, who took [implemented] his Sunna; and after him [came] 'Umar; so both of his Companions took [implemented] his Sunna." (Crone \& Zimmermann 2001: 76; see also 78, 82, 90).

In his discussion on the Najdat, Ibn Dhakwan infers: "They are wrong because they act against the sunna of the Prophet in dealing with them and fail to follow the conduct of (past) people to whom they affiliate in their dealings with their qawm (today)." (Crone \& Zimmermann 2001: 112f). In his criticism on secret killing (as practiced by his opponents) as being against Islamic, he states:

Allah does not command us [to kill in secret] in His book. Nor do we know of any of the allies of Allah in the nations preceding us who legalized (istahalla) anything like it when in a position like ours, so that we would be following their sunna in doing so (fa-naqtadi bi-sunnatihim fi dhalika). We would like the kings of our people (muluk qawmina) to fear Allah, not to follow their whims when truth stands against it, and not to reject a sunnah (wa la yajhadu sunnatan)(Ibid, 134).

He also advises "that we judge according to what Allah has revealed in His Book and that we follow the Sunna of His Prophet and the sunna of the righteous (salihin) among the servants of Allah." (Ibid, 144). The same usage is evident from the Letter of 'Abd Allah b. Ibad al-Marri al-Tamimi (86 AH / 705 CE), to Abd al-Malik b. Marwan (Majmuc al-siyar al-Umaniyyah (MS), 314), preserved in the Sira of Hilal b. Atiyya al-Khurasani (134AH/752CE). Al-Shammakhi mentions in his siyar that Abd Allah b. Ibad often advised 'Abd al-Malik b. Marwan, and as far as al-Shammakhi could recall, he [Ibn Ibad] was Jabir b. Zayd's spokesman for, according to his memory, and he represented the movement in disputes with Kharijites and others (al-Shammakhi 1987: 1/73).

The letter deserves special attention here, as Schacht has referred to it as the earliest document mentioning the term sunna (1982: 17ff; Ennami 2008: 132; Kashif 1986: 325-345). This reference is in line with Schacht's theory that the term sunna was first used to designate the practice of the caliphs and then converted into a newly invented concept of the Sunna of the Prophet (see Bravmann 2009:123). As the above excursion through the early Ibadhi heritage has shown, however, earlier and more diverse documentation of the term exists. Ibn Dhakwan's sira is presumably much older, so is Athar al-Rabi', and the book of Ibn Mahbub al-Ruhayli. All of these earlier sources refer to different dimensions of the term sunna, as we have shown. Schacht may not be blamed for the inaccessibility of earlier sources, however, the conclusion he reached must be seen against the background of his general theory of the development of fiqh and the Sunna as a source of law, and is definitely in need of revision. The mentioned letter is mainly about the Ibadhi evaluation of cUthman as a political figure, Abu Bakr and 'Umar are described as following the Sunna of the Prophet (in governance and otherwise-as a method), whereas cUthman in the course of his caliphate is evaluated as having diverged from it (Kashif1986: 1/328).

The term sunna is therefore used in the general sense as well as with its political denotation: the Sunna of the Prophet as a model, and the sunna of the first two caliphs in following him (Ibid, $1 / 329,333,336,341 \mathrm{ff}$.). Unremarked by Schacht, the letter makes mention of the Book of Allah and 
the Sunna of his Prophet (as sources of law) right in the beginning. As the term has various connotations in different contexts, mentioning sunna in its fiqhi and usuli senses does not exclude the political dimension-and vice versa.

The same usage of sunna as established practice of the first caliphs is continuously present in later writings, such as that of the fourth century scholar al-'Awtabi in his commentary on one legal question, where he states: "And cUmar laid down this sunna." (1990: 4/160). Even though the term sunna is used for the established practice of Abu Bakr and 'Umar, a distinction from the authoritative prophetic Sunna is made, either explicitly or implicitly. Abu Nuh Sa'id b. Zanghil, a North African scholar of the fourth century AH/tenth century AD, divides the Sunna into what is narrated from the Prophet (ma'thura 'an il-nabiyy), and what is established through practice and was followed after him (mustanna istannawha ba'dahu) (n.d. MS no. mim 152, $176 \mathrm{z}$; Baju, 2005:185). The seventh century AH scholar al-Asamm has a definition of sunna that distinguishes between the Sunna of the Prophet (s) and the A'imma: "fa-ma ja'a 'anhu (s) fa-huwa sunna, wa ma ja'a 'an a'immat al-'adl fa-huwa atharun ma mulun bihi" (1984: 2/17).

Another aspect that may be mentioned in this context is described as 'umum al-ta'assi', or following the prophetic Sunna in each and every aspect. Bashir b. Muhammad explains that following the Messenger (pbuh) is the default, until it has been clarified what is specific to him (pbuh) [and not for his community to follow] (Al-Ruhayli n.d. 256; al-Salimi \& Madelung 2011: 24). Abu Ya'qub Yusuf b. Ibrahim Al-Warjalani (570AH/1175CE) confirms this view on the generality of following the sunna - other than what is specific for the Messenger in his dictum: "Islamic law (al-shar') has ordained taking him (pbuh) as guidance and following him unless the evidence shows [a matter] is specific [to the Prophet] (1984: 1/79). The concept of 'umum al-ta'assi is key to understanding the importance of the prophetic Sunna in each and every aspect. Salih b. 'Umar La'li b. Dawud (1347AH/1928CE) mentions that the first generations (al-salaf) were most fervent in following the Prophet in ethics, statements and actions. It can also be perceived that they searched for them with fervour in order to follow him in tabarruk and starting from the right (tayammun) as did Jabir b. Zayd (r.) (n.d. 9). In his legacy (wasiyya) to the Azzaba, he wrote:

In summary, taking him (pbuh) as an example concerns all his ethics, statements and actions-other than what is specific for him (pbuh) - in their entirety without any reluctance or cessation in the first place. This has been known from the practice ( $a d a$ ) of the salaf by necessity. They used to say, "It is among the signs of revering the Prophet (pbuh) to take him as an example, to use his Sunna and follow his statements and actions under all circumstances, to exemplify his orders in whatever is obligatory or recommended, to avoid what he has reprimanded by prohibition or discouragement, and to personify his character traits in times of difficulty as well as of ease, in what he likes or dislikes" (Ibid, 9f).

To conclude, Ibadhi literature may hitherto not have been represented in academic studies on the development of the term sunna and its usage. In the foregoing analysis, this article may have shown that, although it has its own rich and independent heritage, there is virtually no difference other than minor particularities in technical terms and usage - between the Ibadhi and other schools through the different eras of the development of fiqh.

The preceding has shown the different usages of the term sunna in exemplary writings of the rich Ibadhi heritage, in the linguistic, fiqhi and usuli sense as well as at the intersections with hadith, athar and sira. Differences exist in that the Ibadhi madhhab is even more particular in its differentiation of the term sunna wajiba (farida) and sunna mustahabba (fadila), both designating an 
Islamic verdict as established by the prophetic Sunna as a legal source (in the usuli sense), the first the value of the obligatory judgment (wajib), the second the encouraged legal ruling (mandub).

Al Salimi has pointed out, concerning the development of Ibadhi usul, that "the compatibility between ibadi ijtihad and and the ijtihad of other schools is not an indication of subjection, but a sign that they all followed the same methods of reasoning." (2015: 67). Ennami had already previously highlighted that the similarity of all Islamic schools is due to their derivation of their legal systems from the same sources: the Quran, the Sunna and ijma' (Ennami 2008: 164). Although Schacht's theory that the Ibadhi school developed out of the 'orthodox' schools (1979: 163ff) may be considered refuted through the work of Ennami (2008: 163ff), this paper may contribute to viewing the school as one with an independent but nonetheless similar development, based on the usage of the notion of sunna.

\section{References}

Abu al-Hawari, Muhammad b. al-Hawari al-Qari. 1974. Al-Riwaya wa Kanz al-Ghanaya fi Muntaha alGhaya wa Bulugh al-Kifaya fi Tafsir Khamsmi'at aya. Lebanon: Dar al-Yaqizah al-Arabiyya li al-Taa'lif wa al-Tarjama wa al-Nashr.

Abu Shabha, Muhammad b. Muhammad. n.d. Al-Wasit fi Ulum wa Mustalah al-Hadith. Cairo: Dar alFikr al-Arabi.

Abu `Ubayda, Muslim. Masa'il li-Abi 'Ubayda. n.d. MS. Maktabat Muhammad b. Ayyub al-Hajj Sa`id. Wadi Mzab: Jam iyyat al-Turath.

al-Asamm, Abu Muhammad b. Abi `Abd Allah. 1984. Al-Basirah. Oman: Wizarat al-Turath al-Qawmi wa al-Thaqafa.

al-Awtabi, Salama b. Muslim al-Suhari Abu al-Mundhir. 1999. Kitab al-Ibana. Tahqiq. `Abd al-Karim Khalifa. Oman: Wizarat al-Turath al-Qawmi wa al-Thaqafah.

al-Awtabi, Salama b. Muslim al-Suhari Abu al-Mundhir. 1990. Kitab al-Diya'. Oman: Wizarat al-Turath al-Qawmi wa al-Thaqafah.

al-Awtabi, Salama b. Muslim al-Suhari Abu al-Mundhir. 1984. Al-Ansab. Oman: Wizarat al-Turath alQawmi wa al-Thaqafah.

Baba `Ammi, Muhammad b. Musa. 2000. Mu'jam A lam al-Ibadiyya min al-Qarn al-Awwal al-Hijri ila al-`Asr al-Hadir. Vol. 2 "Qism al-Maghrib”. Beirut: Dar al-Gharb al-Islami.

Baju, Mustafa. 2002. Tatawwur 'Ilm al-Usul fi al-Masadir al-Umaniyya. Amman: Manshurat Jami at Ahl al-Bayt, Jam iyyat 'Ummal al-Matabi'.

Baju, Mustafa. 1426/2005. Minhaj al-Ijtihad inda al-Ibadiyya. Muscat: Maktabat al-Jayl al-Wa id.

Al-Battashi, Saif b. Hamud b. Hamid. 2004. Ithaf al-A yan fi Tarikh ba'di 'Ulama' 'Uman. 2nd print. Oman: Maktabat al-Mustashar al-Khass li-Jalalat al-Sultan li al-Shu'u al-Diniyya wa alTarikhiyyah.

Bravmann, Meir Max. 2009. The Spiritual Background of Early Islam: Studies in Ancient Arab Concepts. Leiden: Brill.

Boulrawah, Ibrahim b. 'Ali (ed.). 2006. Mawsu'at Athar al-Imam Jabir b. Zayd al-Fiqhiyyah. Muscat: Maktabat Masqat.

Bouzenita, Anke. 2001. Abdarrahman al-Auza'i, ein Rechtsgelehrter des 2. Jahrhunderts d.H. und sein Beitrag zu den Siyar. Erarbeitet auf Grundlage des k. ar-Radd 'ala siyar al-Auza'i. Ph.D. Thesis. Berlin: Klaus Schwarz Verlag. Islamkundliche Untersuchungen Bd. 240.

Al-Busaidi, Ahmed. 2006. The Effect of Doctrinal Conflict on the Science of Hadith. Ph.D. Thesis. University of Edinburgh.

htpps://doi.org/10.24035/ijit.14.2018.001 
Crone, Patricia and Fritz Zimmermann. 2001. The Epistle of Salim Ibn Dhakwan. Oxford: Clarendon Press.

Ennami, Amr. 2008. Studies in Ibadhism. Al-Ibadiyah. Oman: Ministry of Endowments and Religious Affairs, Sultanate of Oman.

al-Farahidi, al-Rabi' b. Habib. n.d. Masa'il Su'ila 'anha al-Rabi' b. Habib MS no. B47. Ghardaia: Maktabat al-Shaykh Salih b. 'Umar La'li.

al-Hadrami, Wa'il b. Ayyub. n.d. Sirat Wa'il b. Ayyub, Dimna Majmu' al-Siyar al-'Umaniyyah. MS. AlDammam: Maktabat al-Imam Ghalib b. `Ali al-Hina'i.

al-Hilali, Salim b. Dhakwan. 1999. Sirat Salim b. Dhakwan. In, Nasir, Muhammad Salih. Minhaj alDa 'wah `inda al-Ibadiyya. Ghardaia: Jam `iyyat al-Turath. Al-Matba`ah al-`Arabiyyah.

Ibn 'Atiyya, Abu Muhammad 'Abd al-Haqq al-Andalusi. 1402/1982. Tafsir Ibn 'Atiyya, al-Muharrir alWajiz fi Tafsir al-Kitab al- 'Aziz. ed. Ahmad Sadiq al-Mallah. Qatar: Mu'assasat Dar al-Ulum.

Ibn Barakah, Abu Muhammad `Abd Allah. n.d. Kitab al-Jami'. 'Isa Yahya al-Baruni (verification and commentary). Muscat: Wizarat al-Turath al-Qawmi wa al-Thaqafah.

Ibn Faris, Ahmad al-Qazwini. 1990. Mu jam Maqayis al-lughah. Beirut: Dar al-Jayl.

Ibn Jami’, Abu Hafs `Amru. 2000. 'Aqidat al-Azzabah. ed. 'Umar b. Ahmad Bazin. 2nd Print. Ghardaia: Al-Matba at al-'Arabiyyah.

Ibn Zanghil, Abu Nuh Sa'id. n.d. Al-Radd 'ala Man Za'ama anna Allaha Istawa ‘ala al-A'rsh ‘ala ma Ya qilu. MS no. mim 152. Ghardaia: Maktabat Al Khalid.

Imam, Muhammad Kamal al-Din. 2013. Mi'at Kitab Ibadi. Tahta ishraf 'Abd Allah al-Salimi. Oman: Wizarat al-Awqaf wa al-Shu'un al-Diniyyah.

Al-Ja'biri, Al-Shaykh Farhat b. 'Ali. 2013. Rasa'il al-Imam Jabir b. Zayd, wa hiya thamaniyya 'Ashara Risala. Oman: Maktabat al-Damiri li al-Nashr wa al-Tawzi`.

Jannaw, Ibn Fata b. Khalaf 'Abd al-Qahhar. 1991. Ajwibat 'Ulama' Fazzan. Al-Majmu` al-Ula, eds. 'Amr Khalifah al-Nami \& Ibrahim Muhammad Talay. Constantine: Matabi` Dar al-Ba`th.

Kashif, Sayyidah Isma il. 1986. Al-Siyar wa al-Jawabat li 'Ulama' wa a'Immat 'Uman. Oman: Wizarat al-Turath al-Qawmi wa al-Thaqafah.

al-Kharusi, Abu al-Mu'thir al-Salt b. Khamis. 1996. Kitab al-Ahdath wa al-Sifat. ed. Jasim Yasin Muhammad al-Darwish. Muscat: Wizarat al-Turath al-Qawmi wa al-Thaqafah.

al-Kharusi, Ahmad. 1435/2014. Istiqlal al-Sunnah bi al-Tashri 'inda al-Ibadiyya. Dirasat ta'siliyya. $2^{\text {nd }}$ print. Oman: Maktab al-Ifta'.

al-Kharusi, Kahlan. 2003. Athar al-Rabi' b. Habib: Edition and Study. Ph. D. thesis. Faculty of Oriental Studies, University of Oxford, St. Cross College.

al-Kharusi, Sa id b. Khalaf (ed.). 1984. Min Jawabat al-Imam Jabir b. Zayd. Oman: Wizarat al-Turath alQawmi wa al-Thaqafah.

al-Khurasani, Abu Ghanim. 2006. Mudawwanat Abi Ghanim al-Khurasani, Mulhaq biha Kitab Ibn 'Abbad wa kitab al-Riba. ed. Yahya b. 'Abd Allah al-Nabhani \& Ibrahim b. Muhammad alAsakir. Muscat: Maktabat al-Jayl al-Wa`id.

al-Khurasani, Abu Ghanim. 2007. Al-Mudawwana al-Kubra li- Abi Ghanim Bishr b. Ghanim al-Isfahani min 'Ulama' al-Qarn al-Thani li al-Hijrah. Bi-ta'aliq Qutub al-A'immah al-Shaykh Muhammad b. Yusuf Atfayyish. ed. Mustafa b. Salih Baju. Oman: Izarat al-Turath wa al-Thaqafah.

al-Kindi, Abu Bakr Ahmad b. 'Abd Allah b. Musa a-Nizwani. 1985. Kitab al-Ihtida' wa al-Muntakhab min Sirat al-Rasul (a.s.s.) wa a'immat wa 'Ulama 'Uman. ed. Sayyidah Isma`il Kashif. Oman: Wizarat al-Turath al-Qawmi wa al-Thaqafah.

al-Kindi, Ibrahim b. Ahmad. 1998. Usul al-Fiqh wa al-Adillah al-Nassiyyah. Oman: Maktabat al-Damiri li al-Nashr wa al-Tawzi'. 
al-Kudami, Abu Sa`id Muhammad b. Sa id. 1306/1985. Al-Jami al-Mufid min Ahkam Abi Sa ì. Oman: Wizarat al-Turath al-Qawmi wa al-Thaqafah.

al-Khurasani, Hilal b. `Atiyyah: Sirat Hilal b. 'Atiyyah, in: n.a. n.d. Majmu `al-Siyar al- 'Umaniyyah. AlDammam: Maktabat al-Imam Ghalib b. 'Ali al-Hina'i.

La'li, Salih b. 'Umar b. Dawud. n.d. Wasiyyat al-Shaykh Salih b. 'Umar La'li li al- Azzabah. Ghardaia: Maktabat La'li Salih.

Madelung, Wilferd. 2003. The epistle of Salim Ibn Dhakwan. Journal of Islamic Studies. January. 14 (1): $72-74$.

Majmu 'a min al-Bahithin. 2012. Mu'jam Mustalahat al-Ibadiyya. $2^{\text {nd }}$. edition. Oman: Wizarat al-Awqaf wa al-Shu'un al-Diniyyah.

al-Mundhiri, Khalfan b. Muhammad. 2017. Mukhtalafal-Hadith wa Atharuhu fi al-Fiqh al-Ibadi. Dirasa Hadithiyya Fiqhiyyah Muqaranah. Ghardaia: Jam iyyat al-Turath.

al-Nami, `Amru Khalifa. 2001. Dirasat ‘an al-Ibadiyya. Tarjamat, Mikha'il Khuri. Beirut: Dar al-Gharb al-Islami.

al-Nafusi, Abu Hafs `Amrus b. Fath. 1999. Usul al-Daynuna al-Safiyya. eds. Hajj Ahmad b. Hammud Sharifi, Mustafa b. Muhammad Sharifi \& Muhammad b. Musa Baba `Ammi. Oman: Wizarat alTurath al-Qawmi wa al-Thaqafah.

Nasir, Muhammad Salih \& Sultan b. Mubarak al-Shaybani. 2006. Mu'jam A'lam al-Ibadiyya min al-Qarn al-Awwal al-Hijri ila al-'Asr al-Hadith, Qism al-Mashriq. Beirut: Dar al-Gharb al-Islami.

Nasir, Muhammad Salih. 1999. Minhaj al-da'wa 'inda al-Ibadiyya. Ghardaia: Al-Matba'a al-'Arabiyya, Jam'iyyat al-Turath.

al-Qanubi, Sa id b. Mabruk. n.d. Muqaddimat fi 'Ulum al-Hadith. MS.

al-Ruhayli, Bashir b. Muhammad b. Mahbub. No date. Kitab al-Musta'nif, MS, Majmu'al-siyar.

al-Sadwikshi, Abu Sitta Muhammad b. 'Umar al-Qasabi. n.d. Hashiyat Abi Sittah `ala Mukhtasar al- 'Adl. MS. Ghardaia: Maktabat al-Hajj Sa'id Muhammad.

al-Sadwikshi, Abu Sittah Muhammad b. 'Umar al-Qasabi. n.d. Hashiyat Kitab al-Wad'. MS. n.l.

al-Salimi, Abdulrahman \& Madelung, Wilferd. 2011. Early Ibadi Literature. Abu al-Mundhir Bashir b. Muhammad b. Mahbub. Kitab al-Rasf fi al-tawhid, Kitab al-Muharaba and Sira. Abhandlungen für die Kunde des Morgenlandes, vol. 75. Im Auftrag der Deutschen Morgenländischen Gesellschaft herausgegeben von Florian C. Reiter. Wiesbaden: Harrassowitz Verlag.

al Salimi, Abdulrahman. 2015. Early Islamic theological influence in jurisprudence. In: MichalakPikulska, Barbara and Eisener, Reinhard, eds. Ibadi Jurisprudence. Origins, Developments and Cases. Studies on Ibadism and Oman, eds Abdulrahman Al Salimi and Heinz Gaube. Hildesheim: Olms Verlag. 6: 55-72.

al-Salimi, Nur al-Din `Abd Allah b. Humayd. 2010. Tal'at al-Shams Sharh Shams al-Usul. Tahqiq: 'Umar Hasan al-Qayya. Oman: Maktabat al-Imam al-Salimi.

al-Salimi, A. 2009. Themes of the Ibadi/Omani Siyar. Journal of Semitic Studies. 54(2): 475-514.

al-Salimi, A. 2010. Identifying the Omani/Ibadi Siyar. Journal of Semitic Studies. Spring. 55(1): 115162.

al-Salmi, Abdulrahman. 2001. The Omani Siyar as a Literary Genre and Its Role in the Political Evolution and Doctrinal Development of Eastern Ibadism, With Special Reference to the Epistles of Khwarizm, Khurasan and Mansura. Ph. D. Thesis. Durham University.

a-Shammakhi, Ahmad b. Sa ìd b. `Abd al-Wahid. 1987. Kitab al-Siyar, ed. Ahmad b. Sàud al-Siyabi. Muscat: Wizarat al-turath al-qawmi wa al-thaqafa.

al-Shammakhi, Abu al-'Abbas Ahmad b. Sa`id. 1989. Sharh Muqaddimat al-Tawhid. ed. Abu Ishaq Ibrahim Atfayyish. (Verification and commentary). Muscat: Maktabat al-Istiqama.

htpps://doi.org/10.24035/ijit.14.2018.001 
Schacht, Joseph. 1982. An Introduction to Islamic Law. Oxford: Clarendon Press.

Schacht, Joseph. 1979. The Origins of Muhammadan Jurisprudence. Oxford: Clarendon Press.

al-Sulaymi, Abu 'Ubayd Hamid b. 'Ubayd b. Musallam al-Azdi al-Sama'ili al-'Umani. 1996. Al-Shams al-Shariqa fi al-Tawhid wa yalihi Sirah fi Itiqad al-Din wa Sifat al-Islam. Oman: Matabi` alNahdah.

al-Talati, 'Amru b. Ramadan Abu Hafs al-Jarbi. n.d. Rafu al-tarakhi fi Mukhtasar al-Shammakhi (MS). Ghardaia: Maktabat al-Hajj Sa`id Muhammad.

al-Talati, 'Amru b. Ramadan Abu Hafs al-Jarbi. No date. Al-'Aqd al-Nadid 'ala Nuktat al-Tawhid [MS § waw/40]. Ghardaia: Maktabat al-Qutub.

al-Talati, 'Amru b. Ramadan Abu Hafs al-Jarbi. n.d. Natijat al-Afkar fi Ta'liq 'Aqidat al-Abrar (MS no. mim 49). Ghardaia: Maktabat al-Shaykh Salih b. 'Umar La'li.

a-Warjalani, Abu Yàqub Yusuf b. Ibrahim. 1984. Al-'Adl wa al-Insaf fi Ma'rifat Usul al-Fiqh wa alIkhtilaf. Oman: Wizarat al-Turath al-Qawmi wa al-Thaqafah.

al-Warjalani, Sulayman b. Ibrahim Babziz. 2009. Al-Imam Muhammad b. Mahbub al-Ruhayli, Hayatuhu wa Atharuhu [Commentary on Abwab min al-Sunnah Mukhtasarah]. Oman: Wizarat al-Turath al-Qawmi wa al-Thaqafah.

al-Zawari, Abu Zaydat 'Abd al-Rahman b. Sulayman. n.d. Al-Wasaya wa al-Raqaba wa al-Sukna wa al'Umara wa al-Shufa (Fatawa li-ba'd a'Imma al-Ibadiyya al-Mutaqaddimin). MS no.111. Dimna Majmu` Jama`ahu `Abd al-Rahman Al-Zawari. Jarbah: al-Maktaba al-Baruniyyah. 